\title{
Grundtvig-Fondets første ti år
}

\author{
Af K.E. Bugge
}

I september 1992 foretog fondet sin 10.de uddeling. I den anledning har fondsstyrelsen ønsket, at en rapport vedrørende perioden 1983-92 blev offentligt fremlagt. Tidligere er offentliggjort en rapport vedrørende 5 års-perioden 1983-87. De indledende oplysninger $\mathrm{i}$ de to rapporter bliver nasten identiske. Kun på et enkelt punkt, nemlig vedrørende tilsynet, er der i løbet af de sidste 5 år sket en ændring i de almindelige forudsætninger for fondets virksomhed.

\section{Generelt om fondet}

N.F.S. Grundtvigs Fond blev stiftet $\mathrm{i}$ forbindelse med Grundtvigs 200 års-jubilæum i 1983. Om fondets tilblivelse er berettet $\mathrm{i}$ årbogen Uddannelseshistorie 1984. Denne beretning skal ikke gentages her. Lad det være tilstrækkeligt at fastslå følgende:

1) I fondets kongeligt konfirmerede fundats af 18/1-1982 $\S 2$ fastsættes følgende formal:

Fondet har til formål at udbrede kendskab til N.F.S. Grundtvigs indsats. Fondet kan i overensstemmelse med Grundtvigs tanker derudover støtte formål, der i almindelighed er »til folkegavn «.

2) Fondsstyrelsen består iflg. fundatsens $\S 5$ af fem medlemmer: 2 udpeges af Kirkeligt Samfund, heraf 1 uden for KS's bestyrelse. 2 udpeges af Dansk Friskoleforening, Foreningen for Folkehøjskoler i Danmark og Foreningen af frie Ungdoms- og Efterskoler, og 1 udpeges af Grundtvig-Selskabet.

Som det fremgår, er mønsteret $\mathrm{i}$ fordelingen af styrelsesposter: 2 kirkelige repræsentanter, 2 fra de grundtvigske skoler og 1 fra Grundtvig-forskningen. KS har overladt den ene af sine 2 poster til Foreningen af Grundtvigske Valg- og Frimenigheder. De tre skolerepræsentanter besætter de to styrelsesposter efter en turnusordning. 
3) Uddeling af tilskud finder sted på Grundtvigs fødselsdag d. 8. september (Fundatsens $\S 6$ ).

4) Tilsynsmyndighed var indtil 1986/87 Undervisningsministeriet, fra 1987-92 Fondsregistret, i 1992 Civilretsdirektoratet og fra 1993 den lokale Skattemyndighed.

\section{Uddelinger 1983-92}

Hvad angår størrelsen af det beløb, der er til rådighed med henblik på uddeling, skal bemærkes følgende: Det var først i løbet af 1984, at fondskapitalen nåede op på den størrelse, der var nødvendig, for at den fra og med 1985 kunne give det »normale « renteafkast på ca. $130.000,-\mathrm{kr}$. Af renteafkastet skal ifølge fundatsens $\S 3$ hvert år henlægges indtil $15 \%$ til imødegåelse af inflationsforringelse.

I løbet af fondets første 10 år er uddelt $\mathrm{i}$ alt 232 tilskud til et samlet beløb på 1.114.500,- kr. De beløb, der blev uddelt i de enkelte år, fordeler sig som følger:

$\begin{array}{lr}1983 & 25.000,- \\ 1984 & 66.000,- \\ 1985 & 111.000,- \\ 1986 & 112.000,- \\ 1987 & 120.000,- \\ 1988 & 125.000,- \\ 1989 & 155.000,- \\ 1990 & 130.000,- \\ 1991 & 140.000,- \\ 1992 & \frac{130.500,-}{1.114 .500,-}\end{array}$

Dette giver et gennemsnit pr. tilskud på 4.804,- kr. Mindste tilskud er 600,- kr., og største enkelt-tilskud er 20.000,- kr. Det ekstraordinært høje tilskudsbeløb i 1989 skyldes dels genbevilling af et returbeløb, dels tilskud fra Super-Chancen. Endvidere noteres, at det samlede beløb nu er nået op over en million. Også det er en slags jubilæum! 
Af udenlandske bevillingsmodtagere er der ikke mange, men dog nogle: Norge - 4, Sverige - 2, Island - 2, England - 1, Tyskland - 7, Schweiz - 2, Indien - 2, Nigeria - 1, Kina - 1.

Af den ovenfor citerede formålsparagraf fremgår, at tilskud skal uddeles $\mathrm{i}$ henhold til to formål: Et overordnet formål, som er at udbrede kendskab til N.F.S. Grundtvigs indsats, og et underordnet formål, som er at støtte initiativer, der i almindelighed er »til folkegavn«. I henhold til disse bestemmelser og deres indbyrdes prioritering er de fleste tilskud (i alt 993.500,-) udbetalt med henblik på at støtte projekter, der falder ind under hovedformålet, og en mindre andel (i alt 121.000,-) er udbetalt med henblik på at støtte aktiviteter, der skønnes at være »til folkegavn .

Fordeling af tilskud i henhold til hovedformålet

De her henhørende tilskud kan indordnes under 8 overskrifter:

1. Udgivelse af Grundtvig-tekster, studier over Grundtvig samt Grundtvig-konferencer . . . . . . 414.000,-

2. Studie- og foredragsrejser inden for hovedformålet 130.000,-

3. Udgivelser, der belyser folkehøjskolen . . . . . . 97.000,-

4. Udgivelser, der belyser friskolen . . . . . . . . 39.000,-

5. Udgivelser, der belyser efterskolen . . . . . . 32.000,-

6. Folkeligt oplysningsarbejde . . . . . . . . . . 129.500,-

7. Kirkelig grundtvigianisme . . . . . . . . . 116.000,-

8. Nordisk kulturelt samarbejde . . . . . . . 36.000,993.500,- 
Fordeling af tilskud $i$ henhold til det sekundare formål «folkegavn*

Det er indlysende, at udtrykket »til folkegavn« kan tolkes meget forskelligt. Udtrykket har da også gennem årene givet anledning til adskilllige forespørgsler fra potentielle ansøgere. Også på styrelsens møder har det undertiden givet anledning til debat. Selv om den sekundære bestemmelse således er vanskelig at håndtere, har den ikke desto mindre tilført beslutningsprocessen en fleksibilitet og åbenhed, som også efter styrelsens bedste overbevisning er helt »i overensstemmelse med Grundtvigs tanker«.

I rapporten fra 1987 er disse tilskud søgt fordelt på kategorierne »Socialt arbejde« og »Kulturelt arbejde $\mathrm{i}$ bredere forstand I den konkrete virkelighed, som disse særlige tilskud sigter imod, er de to kategorier imidlertid tæt sammenvævet. Vi finder det derfor nu formålsløst at opretholde den nævnte sondring, som derfor her er opgivet.

Det kan imidlertid være af interesse, at der gives nogle $e k$ sempler på aktiviteter, der er blevet støttet under henvisning til »folkegavn $\ll$ :

- kirkeligt socialt arbejde på Nørrebro og Vesterbro

- KFUK- og KFUM spejderhytter, herunder etablering af handicaptoiletter

- lydbøger til ordblinde

- en kulturfilm

- studier af rytmisk dans

- studier over Finne-børn i Danmark

- kørestolssliske til et forsamlingshus

- publikation af IBA-folkets mundtlige traditioner (Nigeria)

- biblioteksudstyr til to biblioteker i Indien

- lydanlæg til en amatørteaterforening.

Man skulle herefter synes, at der ikke er grænser for, hvad fondet kan støtte. Ikke desto mindre er der grænser. To synspunkter har $i$-så henseende været vejledende. Negativt: At man afviser ansøgninger, der med rimelighed kan forventes imødekommet af andre instanser i samfundet. Positivt: At det givne tilskud skal betyde noget $\mathrm{i}$ det pågældende projekts budget. Det vil sige, 
at man f.eks. ikke har ydet tilskud til projekter i million-klassen, typisk restaureringsarbejder eller større nybygninger.

\section{Afsluttende bemaerkninger}

Ser man tilbage på fondets første ti fordelingsår, kan for det første konstateres, at det er lykkedes i overensstemmelse med fundatsen at markere en klar prioritering mellem hovedformål og sekundært formål. Dernæst konstateres, at der har været en bred og støt voksende interesse for fondet og dets virksomhed. Dette giver sig udslag i det markant stigende antal ansøgninger, i 1983: 22, og i 1992: 122. Antallet af menigheder, der siden 1985 via en årlig kollekt har støttet fondet, er steget støt og roligt fra 52 til $87 . \mathrm{Og}$ fondet modtager løbende større eller mindre gaver fra foreninger og enkeltpersoner.

Ligesom i 1987 kan til slut anføres, at med fondets etablering har Grundtvig-jubilæet i 1983 fået en langtrækkende og - som det synes - gavnlig og påskønnet eftervirkning. 